\title{
Health Care Expenditure of Rural Households in Pondicherry, India
}

Poornima Varadarajan,' Lopamudra Moharana,' Murugan Venkatesan'

\begin{abstract}
Background: Shortcomings in healthcare delivery has led people to spend a substantial proportion of their incomes on medical treatment. World Health Organization (2005) estimates reveal that every year 25 million households are forced into poverty by illness and the struggle to pay for healthcare. Thus we planned to calculate the health care expenditure of rural households and to assess the households incurring catastrophic health expenditure. Methods: A cross-sectional study was conducted in the service area of Sri Manakula Vinayagar Medical College and Hospital from May to August 2011. A total of 100 households from the 4 adjoining villages of our Institute were selected for operational and logistic feasibility. The household's capacity to pay, out of pocket expenditure and catastrophic health expenditure were calculated. Data collection was done using a pretested questionnaire by the principal investigator and the analysis was done using SPSS (version 16). Results: The average income in the highest income quintile was Rs 51,885 but the quintile ratio was 14.98 . The median subsistence expenditure was Rs 4,520 . About $18 \%$ of households got impoverished paying for health care. About $81 \%$ of households were incurring out of pocket expenditure and $66 \%$ were facing catastrophic health expenses of $40 \%$. Conclusion: There was very high out of pocket spending and a high prevalence of catastrophic expenditure noted. Providing quality care at affordable cost and appropriate risk pooling mechanism are warranted to protect households from such economic threats.
\end{abstract}

Key Words: Health expenditures, health services needs and demand, India (Source: MeSH-NLM).

About the Author:

Poornima Varadarajan is a 4th year medical student at Sri Manakula Vinayagar Medical College and Hospital, Pondicherry, India
Submission: July 11, 2012. Accepted: Nov 17, 2012. Process: Peer-Reviewed.

\section{Introduction}

The promotion of health is of fundamental value in itself. It is a vital public good and a basic human right. In this regard, delivery of healthcare is very important for providing preventive, promotive and curative services to the community. ${ }^{1}$

There have been substantial achievements in healthcare in past few decades. However, technological innovation in the health sector has improved the quality of life but has also increased costs especially in middle and low income countries. Shortcomings in healthcare delivery have been largely designated as fragmented care, misdirected care and impoverishing care. ${ }^{2}$ In countries that have no social insurance and where the role of the state is limited, people spend a substantial proportion of their incomes on seeking medical treatment, and in the process get impoverished, thus widening disparities in the health status. ${ }^{3}$ The unpredictability of illness, the lumpiness of health consumption, and the irregular and seasonal nature of incomes make it virtually impossible for the poor to finance their health needs, resulting in a denial of care and poverty. ${ }^{1}$
According to the World Health Organization (2005) estimates, every year 25 million households (more than $100 \mathrm{mi}$ llion people) are forced into poverty by illness and struggle to pay for healthcare. ${ }^{4}$ The decline in public investment in health and the absence of any form of social insurance have heightened insecurities. Considering the Indian scenario, a report by the National Health Accounts reveals that $71 \%$ of the health budget is contributed by the private sector; of which households alone spend about $69 \%$.' It is well known that health expenditure in India is dominated by private spending and this is a reflection of inadequate public spending. The relationship between poverty and ill-health is indisputable. Even relatively small expenditure on health can be financially disastrous for poor households. High out of pocket payment, an absence of risk pooling mechanism in health financing systems, and high level of poverty can result in catastrophic health expenditure. ${ }^{5}$ Thus, the present study was conducted to quantify the health care expenditure of households in rural Pondicherry with these objectives; i) to note the health care expenditure of rural households and ii) to assess if any family is undergoing catastrophic health expenditure. 


\section{Materials and Methods Study Setting}

Pondicherry (Puducherry), district of India has a total population of 946,600 (census 2011) of which the rural population is about 292,208 (30. $87 \%$ ). Per-capita income of Pondicherry at 2009-10 current prices is in indian rupee (Rs) 72,917 (draft annual plan 2011-12, Pondicherry) and about $22 \%$ are below poverty line (2004-05 Pondicherry estimate). ${ }^{6}$ Pondicherry ranks quite high compared to India in terms of fulfillment of several health infrastructure indicators. The total health care expenditure is Rs 80 but the per-capita expenditure is Rs 783 (budget estimate, 2003-04).

\section{Study Design and Sampling}

We planned to study the total health spending so that the burden on households can be commented on. Moreover, to get a better picture of rural areas we studied the rural households. A cross-sectional study was designed and conducted from May to August 2011. We covered four villages, situated within 2-4 kilometers of our Institute (Sri Manakula Vinayagar Medical College and Hospital), for operational and logistic feasibility. The villages were Madagadipet (1174), Kalitheerthalkuppam (1120), Kuchipalayam (158) and PS palayam (441) which constituted our sampling frame and the list of houses of the respective villages were collected from the PHC registers (2011). We planned to survey a total of one hundred households. From the total number of households of the four villages (2893), all sampled households were included in the study. A proportionate sampling method was adopted to draw the sample from the household numbers of each village. The streets in each village were selected by simple random technique. Systematic random sampling method was adopted to select every third household in each street. Initially, a pilot study was conducted to assess and modify the logistic problems expected during the main study.

\section{Parameters}

The total household income and expenses were calculated. For expenditure on health, both direct and indirect expenses were assessed. Direct expenses were costs incurred for the defined medical problem (consultations, investigations, medicines etc.) and the indirect cost included collateral expenses due to the illness (travel, food, loss of wages etc.). We considered the expenses incurred by the households both for their outpatient and inpatient consultations. To avoid recall bias in expenditure, a one month recall period for any OPD consultations and 3 months for any in-patient admissions was considered. For our calculations, we used equivalent household size (household size 0.56$)^{8}$ instead of average household size. The various heads of expenses of the households were determined and for accuracy of food expenditure, equivalized food expenditure was calculated. The subsistence expenditure per (equivalent) capita or the poverty line was determined and the subsistence expenditure (poverty line*equivalent household size) was calculated. The household's capacity to pay (non subsistence effective income of households), out of pocket expenditure (OOP), burden of health payment and catastrophic health expenditure (CHE) was calculated adopting the methodology described by $\mathrm{Xu} \mathrm{K}$ et al. ${ }^{8}$ OOP expenditure is defined as the payment made by families for health care and include out of pocket spending on deductibles and other forms of cost sharing such as co-payments and co-insurance and direct expenditure of health care services equipments and supplies not covered by insurance. OOP in our study was the net of insurance reimbursements and did not include indirect expenses (health-related travel and food). CHE is defined as the level of 00P expenditure that exceeds some fixed proportion of household income or household capacity to pay. ${ }^{9,10}$ For the purpose of our study, if a household's total OOP equaled or exceeded $40 \%$ of the household's capacity to pay (non subsistence effective income of the household or income available after basic needs have been met), it was considered to be facing CHE. We also calculated the households that are poor (total household expenditure less than its subsistence spending) and the non-poor households that were impoverished by health payments.

\section{Results}

The socio-demographic profile of the total households surveyed is described in Table 1. We noted that the majority belonged to the Hindu religion ( $94 \%)$. The various castes were $\mathrm{OBC}(50 \%), \mathrm{MBC}(44 \%)$ and the forward casts $(6 \%)$. About $81 \%$ houses were pucca houses and the majority ( $93 \%)$ were nuclear families. The median 'total' and 'percapita' income of the households were Rs 10,000 and Rs 2,333 respectively. The average income in the highest (5th) quintile was Rs 51,885 but the "quintile ratio" (richest to poorest) was 14.98 . A majority (72\%) possessed pink ration cards and $8 \%$ did not have any ration card. However, those who participated in different income-generating activities and in self-help groups were $7 \%$ and $2 \%$ respectively. None of the households had health Insurance. The "equivalent household size" was 2.26 and the median "equivalized per capita household expenditure" was Rs 2323 where as the median "equivalized food expenditure" was Rs 1379. From the food expenditure, the subsistence expenditure per (equivalent) capita or the poverty line was calculated as Rs 2,080 and thus the median "subsistence expenditure" was calculated to be Rs 4,520 .

The health facilities preferred by the majority of the households were governmental (24\%) and private ( $74 \%$ ). About $1 \%$ preferred both private and governmental facilities and the remaining $1 \%$ preferred chemist shops. About $69 \%$ had reported outpatient illnesses and $35 \%$ had inpatient illnesses within our specified period of recall. The common outpatient illnesses were fever, cough and cold, diarrhea, body and joint pains, gastritis, poor vision, pregnancy, allergy, TB, 
Table 1. Socio-demographic characteristics of the study participants

\begin{tabular}{lc}
\hline Characteristic & $\begin{array}{c}\% \\
\mathrm{n}=100\end{array}$ \\
\hline Religion & \\
\hline Hindu & 94 \\
\hline Muslim & 5 \\
\hline Christian & 1 \\
\hline Housing type & \\
\hline Pucca & 81 \\
\hline Kutcha & 8 \\
\hline Semipucca & 11 \\
\hline Family type & \\
\hline Nuclear & 93 \\
\hline Joint & 7 \\
\hline
\end{tabular}

Possession of ration cards

\begin{tabular}{|c|c|}
\hline Pink & 72 \\
\hline Yellow & 20 \\
\hline No card & 8 \\
\hline \multicolumn{2}{|c|}{ Income generating activities } \\
\hline No & 93 \\
\hline Yes & 7 \\
\hline \multicolumn{2}{|c|}{ Participation in SHC } \\
\hline No & 98 \\
\hline Yes & 2 \\
\hline
\end{tabular}

\section{Health Insurance}

\begin{tabular}{lc} 
No & 100 \\
Yes & 0 \\
\hline Income Quintile & \\
\hline $1^{\text {st }}$ Quintile (Rs 3462)* & 26 \\
\hline $2^{\text {nd }}$ Quintile (Rs 6875)* & 18 \\
\hline $3^{\text {rd }}$ Quintile (Rs 10,188)* & 16 \\
\hline $4^{\text {th }}$ Quintile (Rs 16,781)* & 20 \\
\hline $5^{\text {th }}$ Quintile (Rs 51,885)* & 20 \\
\hline Quintile Ratio (Richest to poorest) & 14.98 \\
\hline Total income (Median) & 10,000 \\
\hline Per capita monthly income (Rs, median) & 2333 \\
\hline Equivalent household size ${ }^{\dagger}$ (Mean \pm SD) & $2.26 \pm 0.4$ \\
\hline $\begin{array}{l}\text { Equivalized household expenditure (Rs per capita, } \\
\text { median) }\end{array}$ & 2323 \\
\hline Equivalized food expenditure ${ }^{\ddagger}$ (Rs, median) & 1379 \\
\hline Subsistence expenditure (Rs, median) & 4520 \\
\hline
\end{tabular}

* Figures in parentheses are average Income in the corresponding income quintile.

† Equivalent household size ${ }^{0.56}$ (Adopted from Xu K etal.).

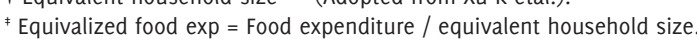

Abbreviations: 00P: Out of Pocket expenditure, Rs: Indian rupee, SHG: Selfhelp group,SD: Standard deviation.
Table 2. Reported illness, capacity to pay and consequence of health expenses incurred per households.

\begin{tabular}{lc}
\hline Characteristic & $\begin{array}{c}\% \\
\mathrm{n}=100\end{array}$ \\
\hline Health facility preferred & 74 \\
\hline Private & 24 \\
Covernmental & 1 \\
\hline Both & 1 \\
\hline Chemist shop & 69 \\
\hline Outpatient illness (Reported within 2 months) & 35 \\
\hline Inpatient illness (Reported within 3 months) &
\end{tabular}

Household spending on health $(n=84$, who reported any illness, as \% of their total Income)

$\begin{array}{ll}<20 \% & 35 \\ 20-50 \% & 14 \\ >50 \% & 35\end{array}$

Household's capacity to pay

$\begin{array}{lc}\text { Rs } 10,000 & 71 \\ \text { Rs } 10,000-30,000 & 18 \\ \text { Rs }>30,000 & 11 \\ \text { 00P incurred } & 81 \\ \text { 00P share of total income } & \\ \leq 50 \% & 48 \\ >50 \% & 33\end{array}$

OOP share of total expenses

\begin{tabular}{lc}
$\leq 50 \%$ & 33 \\
$>50 \%$ & 48 \\
$00 P$ share of capacity to pay & 6 \\
$<20 \%$ & 15 \\
$20-40 \%$ & 60 \\
$>40 \%$ & 29 \\
Poor (Below poverty line) & 18 \\
\hline Impoverishment (Due to health expenses) & \\
\hline
\end{tabular}

* Note: Median 0OP spending per household was Rs 3000. Median subsistence spending (expenditure) of the households was Rs. 4520. The households' capacity to pay is calculated as the non-subsistence effective Income of households. CHE is calculated as OOPCTP $\geq 40 \%$. About $18 \%$ are impoverished paying for their healthcare expenses. Abbreviations: 00P: Out of Pocket expenditure, Rs: Indian rupee.

Table 3. Prevalence of Catastrophic Expenditure by Cut off Levels (of OOPCTP)

\begin{tabular}{cccc}
$\begin{array}{c}\text { Catastrophic } \\
\text { Threshold } \\
\text { (0OPCTP) }\end{array}$ & $\begin{array}{c}\text { No of } \\
\text { Households } \\
\text { with illness } \\
(\mathrm{n}=81)\end{array}$ & $\begin{array}{c}\% \text { of } \\
\text { Households } \\
\text { with Illness }^{\dagger}\end{array}$ & $\begin{array}{c}\text { Household } \\
\text { Expenditure/m } \\
\text { (Median) }\end{array}$ \\
\hline $20 \%$ & 6 & 7 & 520 \\
$20-40 \%$ & 15 & 19 & 600 \\
$>40 \%$ & 60 & 74 & 8025 \\
\hline
\end{tabular}

* CHE, i.e, OOPCTP $\geq 40 \%$ was incurred by $66 \%$.

+ Illnesses include both outpatient and inpatient categories.

Abbreviations: 00P: Out of Pocket expenditure, 0OPCTP: 00P share of capacity to pay. 
Table 4. Health Expenses Incurred across the Expenditure Quintile $(n=100)$

\begin{tabular}{|c|c|c|c|c|c|}
\hline $\begin{array}{l}\text { Expenditure } \\
\text { Quintiles }\end{array}$ & $\begin{array}{c}\text { Median Health } \\
\text { Expenditure (Rs) }\end{array}$ & OOP in Rs (Median) & ООРСТР (\%) & OOPEXP (\%) & Impoverished (\%) \\
\hline $2^{\text {nd }}$ & 625 & 610 & 46 & 20.1 & Nil \\
\hline $3^{\text {rd }}$ & 1775 & 1330 & 49 & 22.7 & 55 \\
\hline $4^{\text {th }}$ & 5710 & 5110 & 68 & 86.9 & 35 \\
\hline
\end{tabular}

Note: Health Expenditure included both direct and indirect expenses but the 00P takes only direct expenses into consideration

Figure 1. Health Expenses Incurred across the Expenditure Quintiles $(n=100)$

OOP (Median) —-Median Health Expenditure (Rs) ----- OOPEXP (\%) -----OOPCTP (\%)

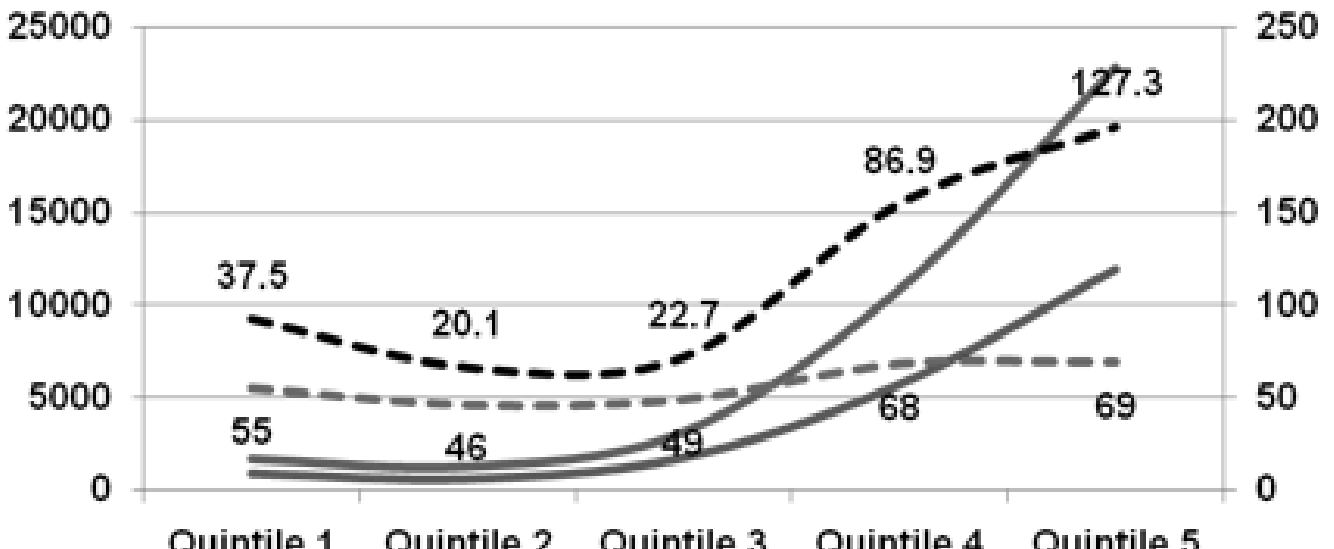

diabetes and hypertension. The common inpatient illnesses were accidents, abdominal pathologies and major abdominal surgeries, obstetric and gynecological complaints, hernias, fractures, tumors and non healing ulcers. Out of the households who reported some illness ( $84 \%$ ), about $49 \%$ were spending about $50 \%$ of their total income and $35 \%$ were spending even $>50 \%$ of their incomes (direct and indirect expenses) on health (Table 2).

Analysis of the households' capacity to pay showed that the majority had the capacity to pay up to Rs 10,000 ( $71 \%$ ) while the remaining had the capacity to pay more. About $81 \%$ of the households were incurring 00P expenses (only direct health expenses were considered) and the median OOP spending per household was Rs 3,000 (Table 2). For $33 \%$ of households, the 00P incurred was $50 \%$ of their total expenses but for $48 \%$ of households, 00P incurred was even $>50 \%$ of their total expenses. About $29 \%$ of the households whose total household expenditure was less than their subsistence spending were already poor, but about $18 \%$ were impoverished by paying for health expenses (Table 2).
The 0OPCTP of $\geq 40 \%$, i.e., CHE was incurred by $66 \%$ of households (Table 2). The percentage of households at catastrophic threshold of $\langle 20 \%, 20-40 \%$ and $>40 \%$ cut off levels were $6 \%, 15 \%$ and $60 \%$ respectively (Table 3 ). We noted that households with higher proportion of reported illnesses and those belonging to higher median household expenditure categories were incurring high CHE. Across the different expenditure quintiles (Table 4, Figure 1), the median health expenditures and median 00P were noted to increase gradually. The OOPCTP and the OOPEXP were highest in the higher expenditure quintiles (4th and 5th quintiles). The OOPEXP was even more than $100 \%$ in the highest (5th) expenditure quintiles. We also noted that there was impoverishment in the middle expenditure quintiles (3rd and 4th); whereas lowest and highest ones did not show impoverishment. Table 5 represents a picture of the households under poverty and those who got impoverished by paying for health care expenses across income quartiles. We noted that the highest number of poor households (65\%) were in the first quartile and the tendency gradually decreased towards the highest quartile. On the contrary, households that faced impoverishment (paying for health care expenses) were $27 \%, 21 \%$ and $24 \%$ in the 2 nd, 3 rd and 4 th quartile respectively. There was no impoverishment noted in the first quartile. 
Table 5. Poverty and Impoverishment across Income Quartiles $(n=100)$

$\begin{array}{cccc}\begin{array}{c}\text { Income } \\ \text { Quartiles }\end{array} & \begin{array}{c}\text { Households } \\ \text { (No) }\end{array} & \begin{array}{c}\text { Poverty, } \\ \text { n (\%) }\end{array} & \begin{array}{c}\text { Impoverishment, } \\ \text { n (\%) }\end{array} \\ 1^{\text {st }} & 26 & 17(65) & 0(0) \\ 2^{\text {nd }} & 30 & 7(23) & 8(27) \\ 3^{\text {rd }} & 19 & 4(21) & 4(21) \\ 4^{\text {th }} & 25 & 1(4) & 6(24)\end{array}$

\section{Discussion}

We present the burden of health payments suffered by the rural households of Pondicherry, India. Information of household expenditure was gathered, particularly on healthcare expenses with respect to their total incomes and expenditures. Even though, most of the households belonged to Prasad's class I $(48 \%)$ of socio economic status, the high quintile ratio (14.98) indicates a gross inequality among the richest and poorest quintiles. About a third of households had a greater subsistence spending than the total expenditure (29\%, poor), which unfortunately was also accompanied by scarce participation in income-generating activities and no health insurance benefits.

It was observed that within the specified recall period of our study, households that reported some illness were spending a major portion of their income on health. Considering the unpredictability and increased frequency of illnesses, health expenditure amounts to a major burden on the households. However, due to the cross-sectional nature of the study we could not determine the frequency of illness. Additionally, preference for private health care facility was supposed to pose a great burden on the households because it usually incurred higher healthcare costs. According to the emerging market report in India from 2007, the private sector accounts for more than $80 \%$ of total healthcare spending." Unless there is a decline in the combined federal and state government deficit, the opportunity for significantly higher public health spending would be limited. The majority of households in our study had low capacity to pay $(71 \%)$ and most preferred a private health care facility (74\%). On the other hand, households were spending even more than half of their total expenses on healthcare from out of pocket and the burden of payment faced was high. We also noted that most households in the first income quartile were already poor $(65 \%)$ whereas those that got impoverished were more likely to be in the higher income quartiles. It could be due to the fact that higher income groups spent more for their healthcare because of higher affordability. This was further evidenced as shown in Table 4 and Figure 1; median health expenditure increased across the expenditure quintiles and OOP and OOPCTP also increased. The high burden of OOP was remarkable in our study; even well above households' total expenses in the highest expenditure quintile (127\%).
According to a report of the National Commission on Macroeconomics and Health 2005, households undertook $75 \%$ of all health spending in the country. ${ }^{1,12}$ Analysis of health care spending in union territories of India in 2004-05 revealed the per-capita health expenditure to be Rs 598 with households spending about $85 \%$ and the government spending at just $9 \% .{ }^{13}$ A study of catastrophic household expenditure on childhood illness in an urban slum of Karnataka, India, showed that all households were undergoing catastrophic expenses at a 5-20\% threshold. $^{14}$

\section{Conclusion}

There was very high 00P spending and high prevalence of catastrophic expenditure noted in our study. Irrespective of the income and expenditure categories, households were incurring CHE and there was substantial amount of income spent on healthcare. We recommend improving the quality of primary care services to make it more accountable to community necessities which would minimize private healthcare expenses. Increased community awareness to participate in income-generating activities to strengthen their household economy is needed. There should be appropriate risk pooling mechanisms to protect households from incurring catastrophic expenses. 


\section{References}

1. Report of the National Commission on Macroeconomics and Health, Ministry of Health and Family Welfare, Covernment of India, New Delhi, August, 2005. Available online at www.who.int/macrohealth/action/ Report\%200f\%20the\%20National\%20Commission.pdf

2. The World Health Report 2008: Primary Health Care, Now more than Ever, The World Health Organization, 2008. Available online at www.who.int/entity/ whr/2008/08_overview_en.pdf

3. Government Health Expenditure in India: A Benchmark Study Undertaken for the MacArthur Foundation, India by Economic Research Foundation, New Delhi, August 2006; 42-2.

4. World Health Report 2005. Make every mother and child count. Geneva: World Health Organization; 2005. Available online at http://www.who.int/ whr/2005/whr2005_en.pdf

5. Xu KD, Evans D, Karrin G, Aguilar-Rivera AM. Technical Brief for Policy Makers. Designing health financing systems to reduce catastrophic health expenditure. World Health Organization, Department of Health Systems Financing, Health Financing Policy, 2005; 1-4.

6. Draft Annual Plan, Puducherry. 2011-2012. Available online at http://pandr. puducherry.gov.in/Plan\%20Formulation/Plan\%20Document/DAP\%202011-12/ pdffiles/int/int.pdf

7. Profile of Union Territory of Pondicherry, 2005; 1-90. Available online at http://www.ncw.nic.in/pdfreports/Gender\%20Profile-Pondicherry.pdf

8. Xu K, Anguliar A, Carrin G, Evans DB, Hanvoravongchai P, Kawabata K,
Klavus J, Knaul F, Murray CMJ, Ortiz JP, Zeramdini R, Annan S, Doorslear EV. Distribution of Health Payments and Catastrophic Expenditures Methodology: Discussion Paper. World Health Organization, Department of Health System Financing and Cluster Evidence and Information for Policy, 2005.

9. Pal R. Analysing Catastrophic 00P Health Expenditure in India: Concepts, Determinants and Policy Implications, Indira Gandhi Institute of Development Research, Mumbai, 2010; 1-25. Available online at http://www.igidr.ac.in/pdf/ publication/WP-2010-001.pdf

10. Su TT, Kouyate B, Flessa S. Catastrophic Household expenditure for Health Care in a Low Income Society: A Study from Nouna District, Burkina Faso. Bulletin of the World Health Organization 2006; 84 (1); 21-27.

11. Healthcare in India: Emerging market report. 2007; 1-22. Available online at http://www.pwc.com/en_GX/gx/healthcare/pdf/emerging-market-reporthc-in-india.pdf

12. National Health Accounts. National Health Accounts Cell, Ministry of Health and Family Welfare, Govt. of India (in collaboration with WHO country office for India). 2004-2005.

13. Gupta I. Draft of Out-of-pocket Expenditures and Poverty: Estimates from NSS 61st Round. Paper presented for consideration of the Expert Group on Poverty, Planning Commission.12 May 2009. Available online from planningcommission.nic.in/reports/genrep/indrani.pdf

14. Patil SS, Berad AS, Angadi MM. A Study to Assess Catastrophic Household Expenditure on Childhood Illness in an Urban Slum in Bijapur. Indian J Community Med 2009;34(4):335-7.

\section{Acknowledgements}

None.

Conflict of Interest Statement ct Funding

The Authors have no funding, financial relationships or conflicts of interest to disclose.

Cite as

Poornima V, Lopamudra M, Murugan V. Health Care Expenditure of Rural Households in Pondicherry, India. Int J Med Students 2013;1(2):74-9. 